\title{
Kajian Biodegradasi Limbah Cair Industri Biodiesel pada Kondisi Anaerob dan Aerob
}

\author{
Mindriany Syafila ${ }^{1}$, Tjandra Setiadi ${ }^{2}$, Abdul Haris Mulyadi ${ }^{2}$ \& Esmiralda $^{1}$ \\ ${ }^{1}$ Fakultas Teknik Sipil dan Lingkungan, Program Magister Teknik Lingkungan \\ ${ }^{2}$ Fakultas Teknologi Industri, Program Magister Teknik Kimia \\ Institut Teknologi Bandung, Jl. Ganesa No. 10 Bandung-40132
}

\begin{abstract}
Abstrak. Penelitian ini bertujuan untuk menangani limbah yang terjadi dari industri biodiesel. Air limbah yang dihasilkan dari industri biodiesel diperkirakan memiliki kandungan organik yang cukup tinggi. dengan demikian perlu dipertimbangkan untuk mengolahnya dengan proses anaerob, sehingga berpotensi untuk mendapatkan produk samping berupa biogas (gas metana). Namun demikian, proses aerob sebagai kelanjutan degradasi secara anaerob harus pula ditinjau, karena masih adanya kandungan organik yang tersisa setelah proses anaerob. Hasil penelitian menunjukkan bahwa efisiensi proses anaerob masih kecil yang ditunjukkan oleh hasil uji Biochemical Methane Potential (BMP) yang hanya sekitar 30\%, akan tetapi dari uji Anaerobic Toxicity Assay (ATA) tampak bahwa limbah cair tidak menghambat pertumbuhan mikroorganisme metanogen. Kinerja proses aerob juga belum menunjukkan hasil yang maksimal, karena efisiensi biodegradasi baru sekitar 75-80\%. Hal ini karena proses aerob seharusnya ditujukan untuk mengolah lebih lanjut efluen proses anaerob.
\end{abstract}

Kata Kunci: industri biodiesel; limbah cair; proses aerob; proses anaerob.

\begin{abstract}
This research was conducted as the starting point on handling the wastewater produced from biodiesel plants. It is predicted as a high organic bearing wastewater. Therefore, an anerobic process has to be considered as the main process for degrading these compounds which will be followed by an aerobic process. However, in this study the fresh produced water was directly exposed to the aerobic process. The result shows that the efficiency of the anaerobic process shown by the Biochemical Methane Potential (BMP) test result was only 30\%, however, the Anaerobic Toxicity Assay (ATA) test pointed that there was no inhibition to the methanogenic microorganisms. The aerobic process also gave the same performance where the biodegradation efficiency was only about $75-80 \%$ which was not the optimum result. It might be due to the aerobic process should be intended for treating the anerobic effluent.
\end{abstract}

Keywords: aerobic process; anaerobic process; biodiesel industry; wastewater.

Makalah diterima redaksi tanggal 15 September 2006, diterima untuk diterbitkan tanggal 6 Agustus 2007. 


\section{$1 \quad$ Pendahuluan}

Kebutuhan solar di Indonesia selalu meningkat dari tahun ke tahun. Pasokan solar untuk memenuhi kebutuhan dalam negeri berasal dari produksi kilang dalam negeri dan impor. Walaupun Indonesia dikenal sebagai negara produsen dan ekportir minyak, impor solar terpaksa dilakukan karena kapasitas pengolahan kilang yang terbatas dan tidak mencukupi untuk memenuhi seluruh permintaan solar dalam negeri. Pada tahun 2006 impor solar Indonesia telah mencapai sekitar 5-6 milyar liter atau sekitar 50 \% dari total kebutuhan saat itu [1]. Berdasarkan laju pertumbuhan konsumsi solar 10 tahun terakhir, yaitu sekitar $6 \%$ pertahun, permintaan solar tahun 2010 diperkirakan akan mencapai 36 milyar liter [2]. Kertergantungan terhadap impor solar ini tentu saja harus dihindari atau paling tidak pengurangannya harus diupayakan. Untuk mengatasi hal tersebut perlu dilakukan sejumlah tindakan, di antaranya penyediaan bahan bakar alternatif pengganti solar.

Ester metil atau sering disebut sebagai biodiesel, merupakan bahan bakar alternatif yang dibuat dari minyak nabati. Dalam pengoperasian mesin-mesin diesel, biodiesel memiliki karakteristik fisika dan kimia yang mirip dengan minyak solar [3]. Disamping itu, biodiesel memiliki keunggulan dibandingkan minyak solar, antara lain: bahan bakunya dapat diperbaharui, memiliki angka setana yang relatif lebih tinggi dan produk yang dihasilkan lebih ramah lingkungan.

Proses pembuatan biodiesel yang lazim dilakukan adalah melalui reaksi transesterifikasi. Pada reaksi ini, trigliserida bereaksi dengan metanol menghasilkan ester metil dan gliserin. Reaksi ini tidak akan berjalan sempurna bila minyak mengandung asam lemak bebas, karena asam lemak bebas dapat bereaksi dengan basa (yang merupakan katalis reaksi) membentuk sabun. Dengan demikian, asam lemak bebas harus disisihkan terlebih dahulu sebelum reaksi transesterifikasi dapat dijalankan. Terdapat beberapa cara untuk menyisihkan asam lemak bebas, diantaranya adalah penyingkiran secara fisik atau dikenal dengan proses pelucutan (stripping) atau dengan reaksi kimia, yaitu dengan reaksi penyabunan atau dengan reaksi esterifikasi mendahului reaksi transesterifikasi. Proses yang umum dipakai dalam pembuatan biodiesel adalah dengan mengetahui terlebih dahulu kandungan asam lemak bebas yang terdapat dalam minyak nabati. Apabila kandungan asam lemak bebas relatif tinggi, maka proses esterifikasi yang dipilih mendahului proses transesterifikasi. Bila kandungan asam lemak bebas relatif rendah, maka reaksi yang terjadi adalah langsung menggunakan proses transesterifikasi.

Terlepas dari proses manapun yang digunakan, maka akan dihasilkan limbah, baik berwujud cair maupun padat (lumpur). Air limbah dihasilkan dari proses 
pencucian produk ester metil dan gliserin. Kandungan dalam air limbah merupakan campuran dari metanol, asam lemak, minyak dan ester metil yang terlarut. Berdasarkan pengalaman dari industri sejenis yang mengandung senyawa-senyawa ini, misalnya limbah yang berasal dari industri minyak sawit, diperkirakan kandungan organik yang dinyatakan dengan COD (Chemical Oxygen Demands ) sekitar 8.000 - 10.000 mg/L dan BOD (Biochemical Oxygen Demands) sekitar 3.000 - $4.000 \mathrm{mg} / \mathrm{L}$, dengan jumlah limbah yang dihasilkan sekitar $2 \mathrm{~m}^{3}$ air limbah/ton produk [4]. Limbah tersebut memiliki potensi besar untuk mencemari lingkungan, oleh karena itu perlu ditangani dengan baik.

Air limbah yang dihasilkan memiliki kandungan organik yang cukup tinggi. Air limbah dengan konsentrasi pencemar organik yang tinggi umumnya diolah secara anaerob, karena pengolahan secara anaerob memungkinkan pengambilan kembali energi dalam bentuk biogas dan jumlah surplus lumpur yang dibuang relatif lebih sedikit. Disisi lain, pengolahan secara aerob memerlukan energi yang tinggi untuk aerasi, banyak menghasilkan lumpur dan memerlukan nutrisi yang lebih banyak bila dibandingkan dengan proses anaerob.

Berdasarkan penelusuran pustaka, dapat disimpulkan bahwa penelitian terhadap air limbah industri biodiesel masih relatif langka. Dengan demikian, diperlukan pengumpulan data karakteristik air limbah industri biodiesel dan uji biodegradasi limbah tersebut baik oleh mikroba anaerob maupun aerob. Pengujian ini akan menentukan strategi penanganan terhadap limbah cair industri biodiesel.

Teknik untuk menguji biodegradasi aerob merupakan metoda yang umum digunakan. Akan tetapi, pengujian biodegradasi secara anaerob dengan teknik Biochemical Methane Potential (BMP) dan Anaerobic Toxicity Assay (ATA) merupakan metoda yang tidak banyak dijumpai dalam pustaka bahasa Indonesia. Oleh karena itu, pada bagian ini, teknik tersebut akan sedikit diulas.

Biochemical Methane Potential (BMP) adalah teknik pengujian anaerobik secara batch untuk memonitor biodegradibilitas relatif sedangkan Anaerobic Toxicity Assay (ATA) merupakan teknik untuk menguji toksisitas limbah dalam proses anaerob. Teknik pegujian ini relatif sederhana dan murah, serta dapat dilakukan di laboratorium tanpa peralatan canggih [5].

BMP adalah ukuran biodegradabilitas sampel [5]. Jika BOD menunjukkan banyaknya polutan organik yang dapat didegradasi oleh proses aerobik, maka BMP menunjukkan COD yang dapat direduksi dan volume metana yang dapat dihasilkan pada pengolahan limbah secara anaerob. Pengujian BMP ini menggunakan alat yang sederhana untuk memonitor biodegradabilitas substrat pada proses anaerobik [6]. Kegunaan BMP adalah sebagai berikut: 
1. Menentukan konsentrasi pencemar organik di dalam limbah yang dapat dikonversi menjadi metana secara anaerob

2. Mengevaluasi efisiensi proses anaerob potensial

3. Menentukan sisa pencemar organik untuk pengolahan anaerob lebih lanjut

4. Menentukan COD yang tidak terbiodegradasi setelah pengolahan.

Dalam proses anaerob, senyawa organik diubah terlebih dahulu menjadi asamasam volatil pada tahap asidogenesa, kemudian asam volatil ini akan diubah menjadi metana pada tahap metanogenesa. Asam volatil utama yang menjadi substrat bagi bakteri pembentuk metana adalah asam asetat. Oleh karena itu, parameter utama untuk proses anaerob adalah mengendalikan pembentukan asam asetat [4]. ATA telah dikembangkan untuk menentukan adanya efek toksik suatu senyawa pada mikroorganisma yang mengkonversi asam asetat menjadi metana. Mikroorganisma pembentuk metana dari asam asetat ini merupakan mikroorganisme yang paling sensitif terhadap toksisitas diantara mikroorganime yang dapat menghasikan metana. Adanya penghambat bagi mikroorganisme metanogenesa akibat penambahan jumlah sampel dapat diketahui dari penurunan laju produksi gas untuk sampel dibandingkan laju produksi gas untuk kontrol [5].

Perbedaan yang penting antara BMP dan ATA adalah adanya penambahan asetat dengan konsentrasi tertentu pada ATA, sedangkan pada uji BMP tidak ada penambahan asetat. Total jumlah biogas yang dihasilkan merupakan yang paling penting pada uji BMP, sedangkan pada ATA yang terpenting adalah laju produksi biogas awal [6].

\section{$2 \quad$ Metodologi Penelitian}

Penelitian dilakukan terhadap limbah cair yang dilakukan dalam skala laboratorium dengan menggunakan model reaktor anaerob dan aerob. Tahapan dalam penelitian ini adalah sbb:

1. Analisa karakteristik fisik, kimiawi, dan mikrobiologi dari limbah

a. Karakteristik limbah akan menentukan jenis proses pengolahan yang akan digunakan. Analisa yang digunakan antara lain dengan menggunakan uji BMP (biochemical methane potential), ATA (anaerobic toxicity assays), selain itu ditentukan pula nilai COD, BOD, padatan tersuspensi dan parameter lain yang berkaitan dengan penentuan karakteristik air limbah.

b. Komposisi materi kimiawi akan menentukan jumlah bahan tambahan yang diperlukan untuk proses biologi dalam pengolahan limbah ini.

2. Karakteristik tingkat degradasi yang dapat dilakukan oleh mikroba. 


\subsection{Uji BMP dan ATA}

Uji ini dilakukan untuk mengetahui kemampuan proses anaerob dalam mengkonversikan senyawa organik menjadi gas metana. Pengujian mengacu pada pustaka [5].

1. Uji ini dilakukan dengan menggunakan botol serum $200 \mathrm{~mL}$

2. Larutan media, air limbah dan lumpur bibit dimasukkan ke dalam botol serum, kemudian disembur dengan gas nitrogen selama 10 menit untuk menjaga kondisi anaerob.

3. Pada hari ke 0, sampel cairan diambil dengan menggunakan jarum suntik, kemudian sampel disentrifugasi dan kandungan COD supernatant dianalisa.

4. Botol serum ditempatkan dalam shaker dengan temperatur dijaga pada $35^{\circ} \mathrm{C}$.

5. Volume gas diukur setiap hari dengan menggunakan syringe, hingga tekanan dalam botol serum kembali ke tekanan atmosferik.

6. Komposisi gas diukur secara berkala dengan menggunakan gas chromatography.

\subsection{Kinerja Proses Aerob}

Pembibitan dan aklimatisasi dilakukan untuk menumbuhkan mikroorganisme yang akan digunakan untuk mendegradasi limbah biodiesel. Bibit berasal dari lumpur tapioka yang ditumbuhkan secara aerob. Pembibitan dan aklimatisasi dilaksanakan lebih kurang sebulan. Aklimatisasi dilakukan dengan memberikan glukosa dengan perbandingan antara glukosa dengan limbah 80\%:20\% seterusnya dikurangi sampai pada akhirnya tidak diberikan glukosa sama sekali.

Selama aklimatisasi DO (dissolved oxygen) dikondisikan untuk selalu di atas 3 $\mathrm{mg} / \mathrm{L}$ dan perbandingan $\mathrm{C}, \mathrm{N}$, dan $\mathrm{P}$ dalam limbah adalah 100, 5, dan 1 [7]. Penambahan unsur runut (trace element) dillakukan selama pengoperasian karena perbandingan $\mathrm{C}, \mathrm{N}$, dan $\mathrm{P}$ dalam limbah biodiesel belum mencukupi. Parameter yang akan dianalisis selama aklimatisasi adalah kandungan organik (mg/L $\mathrm{KMnO}_{4}$ ), VSS, $\mathrm{pH}$, dan temperatur.

Pengoperasian reaktor dilakukan dalam beberapa variasi konsentrasi COD yaitu; $1000 \mathrm{mg} / \mathrm{L}, 2000 \mathrm{mg} / \mathrm{L}, 4000 \mathrm{mg} / \mathrm{L}$, dan $6000 \mathrm{mg} / \mathrm{L}$. Masing-masing konsentrasi dioperasikan pada ketiga reaktor yang telah disiapkan dengan menggunakan media yang telah diaklimatisasi sebelumnya. Selama pengoperasian dilakukan penambahan trace mineral dan menjaga agar kandungan DO selalu berada diatas $3 \mathrm{mg} / \mathrm{l}$. Parameter yang dianalisis adalah COD, VSS, dan $\mathrm{pH}$ dan temperatur. 


\section{$3 \quad$ Hasil dan Pembahasan}

Bagian ini akan dibagi menjadi tiga kelompok, yaitu uji karakteristik air limbah, pengujian proses anaerob dan uji biodegradasi secara aerob.

\subsection{Karakteristik Air Limbah Industri Biodiesel}

Pada sub bab ini akan terlebih dahulu dibahas mengenai karakteristik air limbah industri biodiesel yang digunakan pada penelitian. Pada Tabel 1 ditampilkan karakteristik air limbah industri biodiesel.

Tabel 1 Karakteristik air limbah industri biodiesel.

\begin{tabular}{|c|c|c|c|}
\hline No & Parameter & Satuan & Hasil \\
\hline & Fisika & & \\
\hline 1 & Temperatur & ${ }^{0} \mathrm{C}$ & 27 \\
\hline 2. & Zat padat terlarut & $\mathrm{mg} / \mathrm{L}$ & 24454 \\
\hline 3. & $\begin{array}{l}\text { Zat padat tersuspensi } \\
\text { Kimia }\end{array}$ & $\mathrm{mg} / \mathrm{L}$ & 1900 \\
\hline 1. & $\mathrm{pH}$ & $\mathrm{mg} / \mathrm{L}$ & 10,17 \\
\hline 2. & Besi terlarut (Fe) & $\mathrm{mg} / \mathrm{L}$ & 0,30 \\
\hline 3. & Mangan terlarut (Mn) & $\mathrm{mg} / \mathrm{L}$ & $<0,02$ \\
\hline 4. & Barium (Ba) & $\mathrm{mg} / \mathrm{L}$ & $<0,01$ \\
\hline 5. & Tembaga $(\mathrm{Cu})$ & $\mathrm{mg} / \mathrm{L}$ & $<0,03$ \\
\hline 6. & Seng (Zn) & $\mathrm{mg} / \mathrm{L}$ & 2.510 \\
\hline 7. & Krom heksavalen $(\mathrm{Cr}+6)$ & $\mathrm{mg} / \mathrm{L}$ & $<0,006$ \\
\hline 8. & Krom total $(\mathrm{Cr})$ & $\mathrm{mg} / \mathrm{L}$ & $<0,05$ \\
\hline 9. & Cadmium (Cd) & $\mathrm{mg} / \mathrm{L}$ & $<0,005$ \\
\hline 10. & Raksa (Hg) & $\mathrm{mg} / \mathrm{L}$ & $<0,001$ \\
\hline 11. & Timbal (Pb) & $\mathrm{mg} / \mathrm{L}$ & $<0,01$ \\
\hline 12. & Stanum (Sn) & $\mathrm{mg} / \mathrm{L}$ & $<0,002$ \\
\hline 13. & Arsen (As) & $\mathrm{mg} / \mathrm{L}$ & $<0,001$ \\
\hline 14. & Selenum (Se) & $\mathrm{mg} / \mathrm{L}$ & $<0,007$ \\
\hline 15. & Nikel (Ni) & $\mathrm{mg} / \mathrm{L}$ & $<0,06$ \\
\hline 16. & Kobalt (Co) & $\mathrm{mg} / \mathrm{L}$ & $<0,05$ \\
\hline 17. & Sianida (CN) & $\mathrm{mg} / \mathrm{L}$ & $<0,01$ \\
\hline 18. & Sulfida (H2S) & $\mathrm{mg} / \mathrm{L}$ & $<0,01$ \\
\hline 19. & Fluorida $(\mathrm{F})$ & $\mathrm{mg} / \mathrm{L}$ & 0,08 \\
\hline 20. & Klorin bebas (CI2) & $\mathrm{mg} / \mathrm{L}$ & 0,06 \\
\hline 21. & Amoniak bebas (NH3-N) & $\mathrm{mg} / \mathrm{L}$ & 2,83 \\
\hline 22. & Nitrat (NO3-N) & $\mathrm{mg} / \mathrm{L}$ & 0,30 \\
\hline 23. & Nitrit (NO2-N) & $\mathrm{mg} / \mathrm{L}$ & 0,06 \\
\hline 24. & Senyawa oragnik sebagai BOD5 & $\mathrm{mg} / \mathrm{L}$ & $65.689,13$ \\
\hline 25. & Senayawa organik sebagai COD & $\mathrm{mg} / \mathrm{L}$ & 152.079 \\
\hline 26. & Senyawa aktif biru metilen & $\mathrm{mg} / \mathrm{L}$ & 7,81 \\
\hline 27. & Fenol & $\mathrm{mg} / \mathrm{L}$ & 0,016 \\
\hline 28. & Minyak dan lemak & $\mathrm{mg} / \mathrm{L}$ & 0,29 \\
\hline
\end{tabular}




\begin{tabular}{llll}
\hline No & Parameter & Satuan & Hasil \\
\hline 29. & Fosfat & $\mathrm{mg} / \mathrm{L}$ & 7,7 \\
30. & TKN & $\mathrm{mg} / \mathrm{L}$ & 9,34 \\
\hline
\end{tabular}

Berdasarkan tabel diatas, dapat dijelaskan bahwa kandungan senyawa organik $\left(\mathrm{BOD}_{5}\right.$ dan $\left.\mathrm{COD}\right)$ yang terdapat dalam limbah sangat tinggi (melebihi baku mutu minimum). Perbandingan nilai BOD terhadap nilai COD kurang lebih 43\%. Hal ini berarti bahwa proses biologi secara aerob dapat diterapkan, karena hampir setengah dari senyawa organic merupakan senyawa yang mudah terbiodegradasi (dinyatakan dalam BOD). Namun demikian, masih ada setengah lagi kandungan senyawa organik yang harus ditangani. Mengingat kemungkinan besar senyawa organik yang terakhir ini merupakan senyawa yang agak sulit terbiodegradasi, proses anaerob tampaknya menjadi alternatif untuk menanganinya.

\subsection{Uji Proses Anaerob}

Uji proses anaerob akan meliputi BMP dan ATA.

\subsubsection{Uji BMP}

Uji BMP (Biochemical Methane Potential) adalah teknik pengujian anaerobik secara batch untuk memonitor biodegradibilitas relatif. BMP adalah ukuran biodegradabilitas sampel [5]. BMP menunjukkan COD yang dapat direduksi dan volume metana yang dapat dihasilkan pada pengolahan limbah secara anaerob.

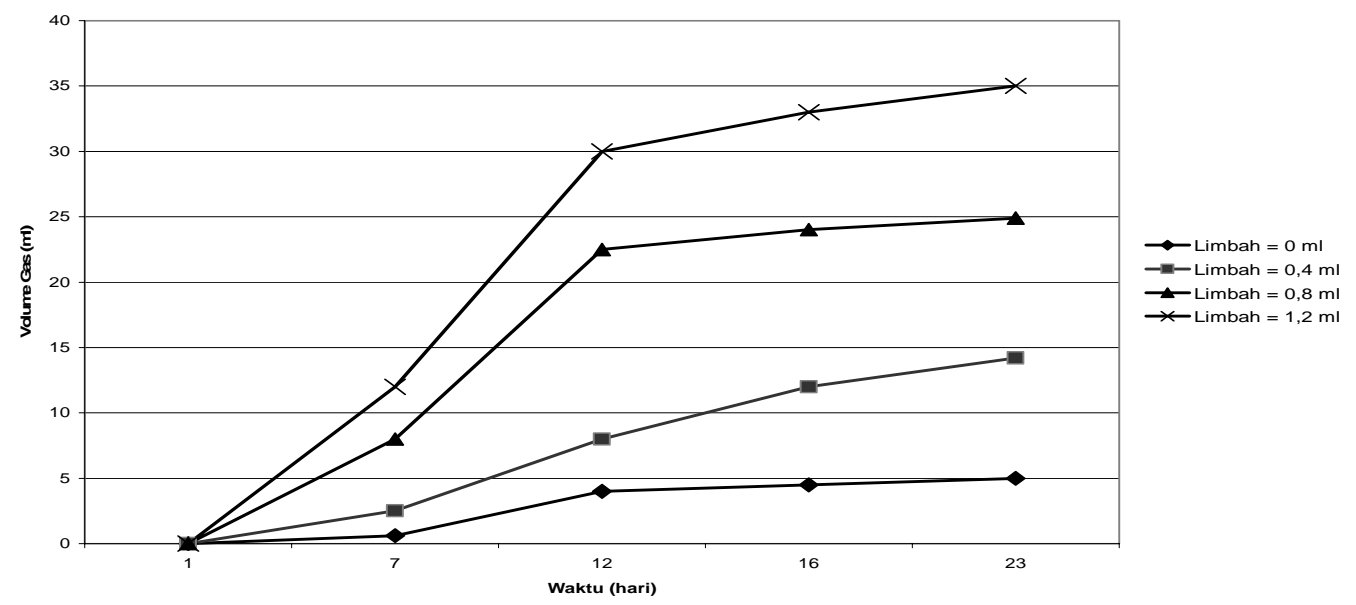

Gambar 1 Produksi gas kumulatif uji BMP. 
Pada Gambar 1 ditampilkan hasil uji BMP yang diperoleh sampai hari ke-23, dengan volum limbah digunakan antara $0,4 \mathrm{~mL}$ sampai $1,2 \mathrm{~mL}$, masing-masing volum limbah dilakukan triplo dan dihitung secara kumulatif kemudian dirataratakan. Gambar 1 menunjukkan produksi gas kumulatif pada uji BMP.

Volume limbah $0 \mathrm{~mL}$ merupakan blanko, dimana limbah tidak ada yang dimasukkan. Berdasarkan gambar dapat disimpulkan bahwa volum gas yang dihasilkan akan naik seiring dengan bertambahnya periode inkubasi (waktu). Dari data kumulatif sampai hari ke-23, dilakukan perhitungan banyaknya gas metan yang diproduksi dan diperoleh hasil bahwa sampai dengan hari ke-23 gas metan yang dihasilkan sebanyak $70 \%$ gas metan. Perhitungan pada pengujian BMP sebagai berikut:

$$
\begin{aligned}
& \text { BMP }=(\text { Kumulatif sampai hari ke-23 volum sampel }- \text { kumulatif sampai } \\
& \text { hari ke-23 blanko }) \text { X 0,7 X }(1 / 395 \mathrm{~mL}) \text { X } 1000 \times(1 / \text { volum } \\
& \text { sampel })
\end{aligned}
$$

Besarnya perbandingan BMP terhadap COD dapat dilihat pada tabel 2 . Perbandingan BMP terhadap COD dilakukan untuk mengetahui kemudahan air limbah industri biodiesel terbiodegradasi secara anaerob.

Tabel 2 Perbandingan BMP terhadap COD.

\begin{tabular}{c|ccc}
\hline & $\begin{array}{c}\text { Volume } \\
\text { Limbah 0,4 ml }\end{array}$ & $\begin{array}{c}\text { Volume } \\
\text { Limbah 0,8 ml }\end{array}$ & $\begin{array}{c}\text { Volume } \\
\text { Limbah 1,2 ml }\end{array}$ \\
\hline BMP, mg/L & 40462,00 & 45338,00 & 44500,00 \\
COD, mg/L & 152640,00 & 152640,00 & 152640,00 \\
Rasio BMP/COD & 0,27 & 0,30 & 0,29 \\
\hline
\end{tabular}

Berdasarkan perhitungan BMP dan data Tabel 2 dapat disimpulkan bahwa produksi gas metan sampai hari ke-23 berada pada rentang 27-30\%, artinya biodegradasi air limbah industri biodiesel secara anaerob rendah (kurang dari 0,5 ). Hal ini dimungkinkan akibat kandungan garam dalam air limbah industri biodiesel yang sangat tinggi, serta waktu biodegradasi air limbah industri biodiesel yang belum cukup.

\subsubsection{Uji ATA}

Gambar 2 menunjukkan produksi gas kumulatif yang dihasilkan dengan metode pengujian ATA. Laju produksi gas maksimum untuk masing-masing sampel pada waktu yang sama merupakan hasil perbandingan antara laju produksi gas untuk sampel dengan laju produksi gas rata-rata untuk kontrol. Perbandingan ini dinamakan maximum rate ratio (MRR). 


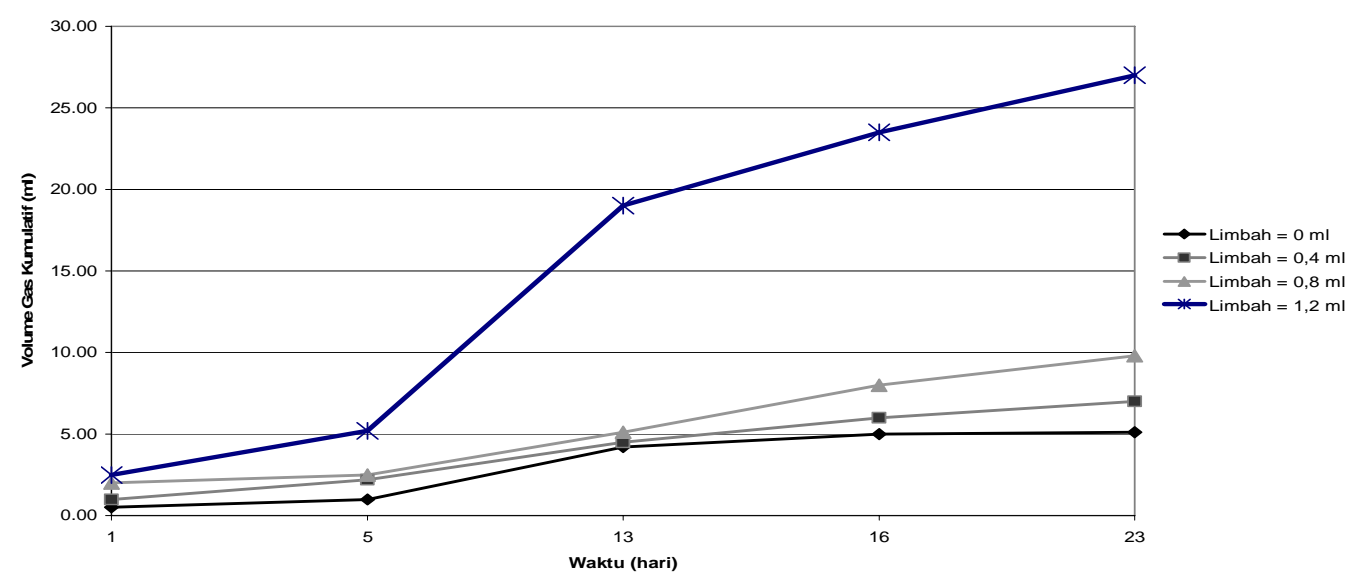

Gambar 2 Produksi gas kumulatif uji ATA.

Hambatan bagi mikroorganisme metanogenesa ada jika MMR $<0,95$, dan jika MRR < 0,9 maka ada hambatan yang signifikan bagi mikroorganisme metanogenesa. MRR merupakan angka yang menggambarkan laju produksi gas maksimum, yang pada penelitian ini tercapai pada waktu reaksi 5 hari. Nilai MRR yang diperoleh pada periode lima hari dapat dilihat pada Tabel 3.

Tabel 3 Tabel MRR.

\begin{tabular}{c|cccc}
\hline & $\begin{array}{c}\text { Volume limbah } \\
\mathbf{0 ~ m l}\end{array}$ & $\begin{array}{c}\text { Volume limbah } \\
\mathbf{0 , 4} \mathbf{~ m l}\end{array}$ & $\begin{array}{c}\text { Volume limbah } \\
\mathbf{0 , 8}\end{array}$ & $\begin{array}{c}\text { Volume limbah } \\
\mathbf{1 , 2} \mathbf{~ m l}\end{array}$ \\
\hline Gas & & & & \\
Kumulatif & 0,93 & 2.00 & 2,67 & 5,67 \\
MRR & & 2,14 & 2,86 & 6,07 \\
\hline
\end{tabular}

MRR yang diperoleh besarnya $>0,95$, dapat disimpulkan bahwa pada rentang volum limbah $0,4 \mathrm{~mL}$ sampai $1,2 \mathrm{~mL}$ belum menunjukkan adanya hambatan terhadap mikroorganisme metanogenesa selama pengujian. Dengan kenaikan volume limbah maka pembentukan gas metan tidak berkurang (tidak terhambat).

\subsection{Biodegradasi Aerob Limbah Biodiesel}

Setelah aklimatisasi tercapai yang ditunjukkan dengan laju penggunaan senyawa organik yang mendekati konstan, seperti yang ditunjukkan pada Gambar 3, penelitian dilanjutkan untuk memperoleh kinerja proses aerob pada berbagai konsentrasi senyawa organik yang dinyatakan sebagai COD. Proses aerob ditujukan untuk menurunkan senyawa organik pada level yang lebih rendah (kurang dari 4000 mg/L COD). Hal ini dikarenakan pada level yang 
lebih tinggi, energi yang dibutuhkan untuk proses aerob juga akan meningkat, sehingga tidak sebanding dengan hasil yang akan diperoleh. Jadi, untuk menguraikan senyawa organik dalam konsentrasi yang sangat tinggi, proses anaerob lebih diandalkan untuk diaplikasikan. Proses aerob umumnya digunakan setelah proses anaerob berjalan, sehingga bertindak sebagai "polishing” saja. Namun demikian pada penelitian ini, proses aerob digunakan untuk mengolah limbah biodiesel segar yang belum melalui proses anaerob. Hal ini dikarenakan uji proses anaerob dan aerob berjalan paralel.

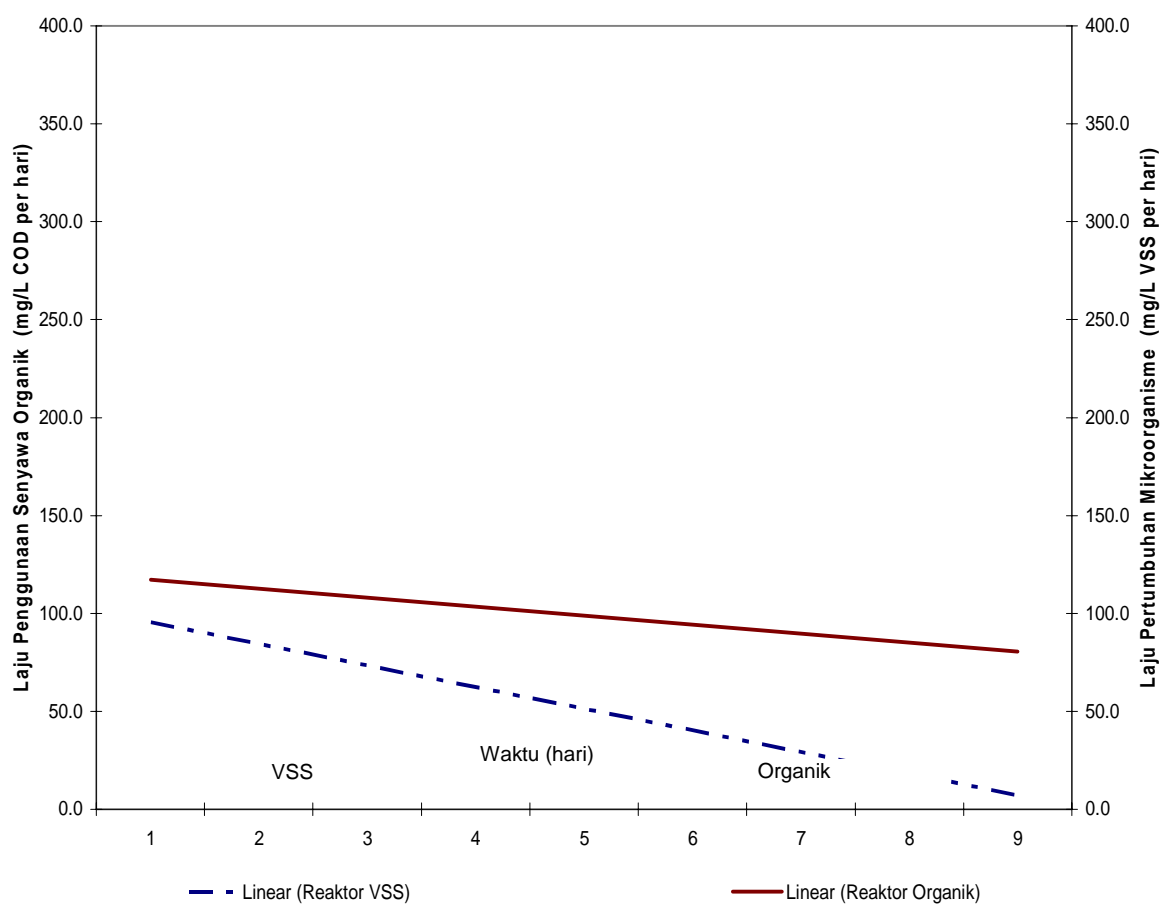

Gambar 3 Laju penggunaan senyawa organik dan laju pertumbuhan mikrorganisma pada tahap aklimatisasi.

Variasi konsentrasi senyawa organik yang ditinjau adalah 1000, 2000 dan 4000 $\mathrm{mg} / \mathrm{L}$ COD dalam suatu sistem batch. Data percobaan untuk ketiga variasi konsentrasi ini dapat dilihat pada Gambar 4, 6 dan 8 untuk penyisihan senyawa organik, sedangkan pertumbuhan mikroorganisme dapat dilihat pada Gambar 5, 7 dan 9. 


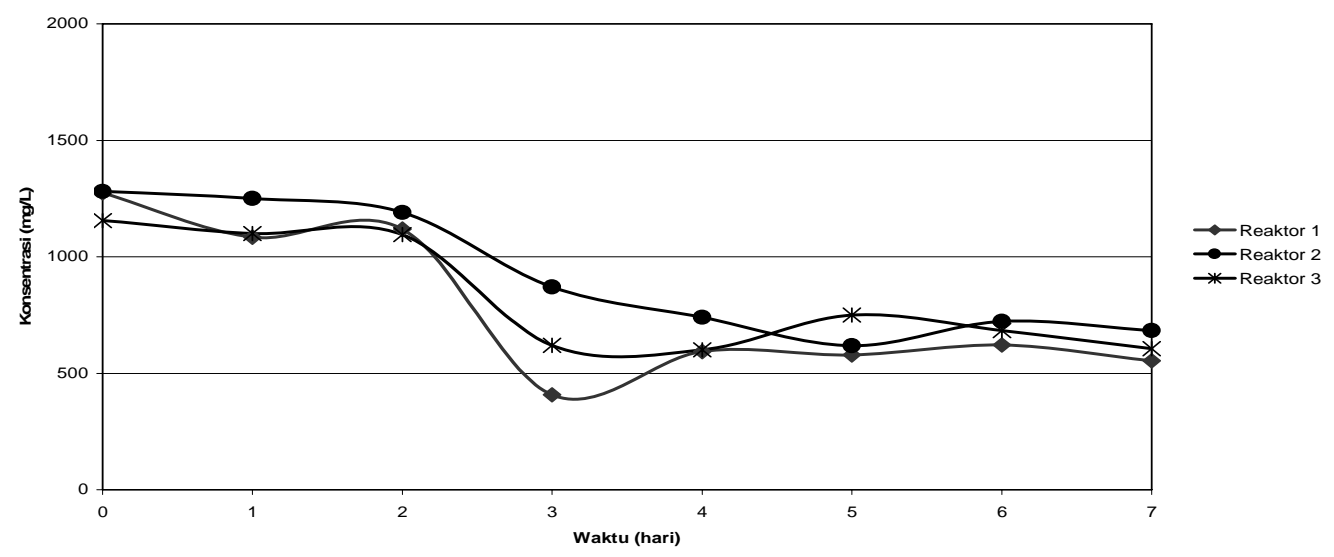

Gambar 4 Pola penyisihan senyawa organik pada konsentrasi $1000 \mathrm{mg} / \mathrm{L}$ COD secara aerob.

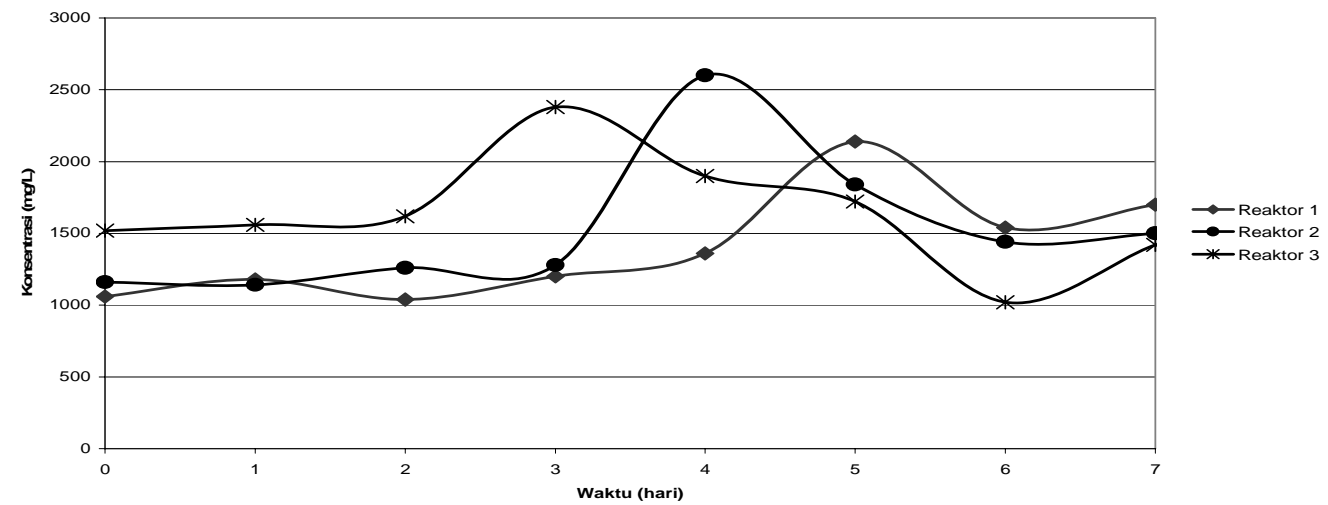

Gambar 5 Pola pertumbuhan mikroorganisma pada konsentrasi 1000 mg/L COD secara aerob.

Jika dilihat dari pertumbuhan mikroorganisme, kecenderungan yang ada adalah bahwa pada beberapa hari pertama masih terjadi kematian dan pertumbuhan silih berganti, dan pada akhirnya tercapai suatu kondisi tunak dimana pertumbuhan mikroorganisma masih mendekati konstan. Apabila dilihat dari jumlahnya, kandungan VSS yang terukur pada akhir proses degradasi memang relatif kecil, tetapi hal ini tidak menjadi masalah mengingat kemungkinan besar VSS ini mengandung mikroorganisma yang memang sudah beradaptasi penuh terhadap limbah biodiesel. 


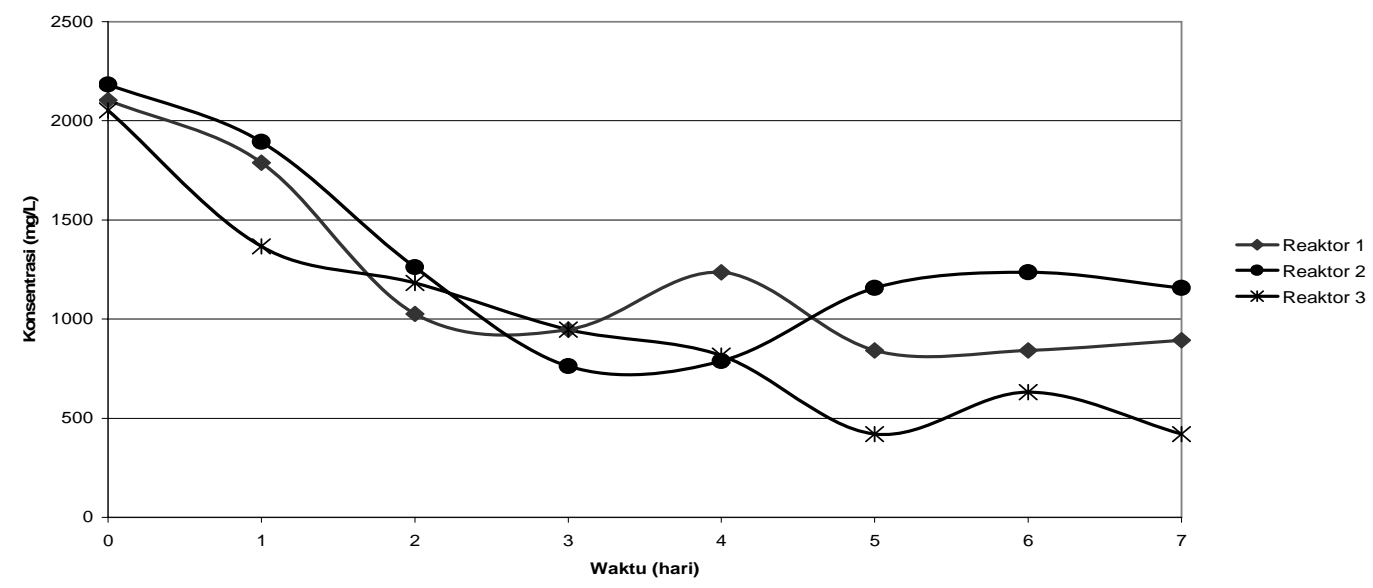

Gambar 6 Pola penyisihan senyawa organik pada konsentrasi 2000 mg/L COD secara aerob.

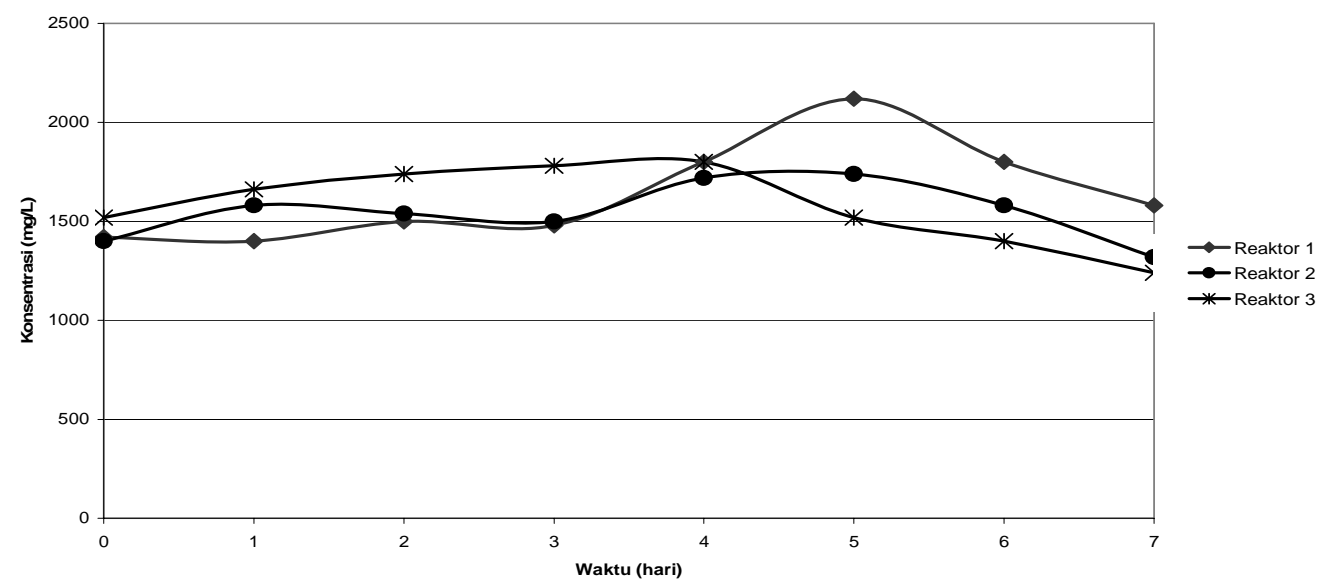

Gambar 7 Pola pertumbuhan mikroorganisma pada konsentrasi 2000 mg/L COD secara aerob.

Dari data-data tersebut terlihat bahwa pada konsentrasi COD tertinggi yaitu sekitar $4000 \mathrm{mg} / \mathrm{L}$, efisiensi penyisihan dapat mencapai 80\%. Nilai ini diperoleh dari suatu sistem batch. Apabila sistem ini akan diterapkan di industri yang pada umumnya menggunakan proses kontinu, maka diperlukan penelitian lebih lanjut. 
Dengan demikian, jika proses anaerob berjalan baik sehingga di akhir prosesnya kandungan COD bisa mencapai 4000-5000 mg/L, pada akhir proses aerob, efluen akan mengandung 800-1000 mg/L COD. Nilai ini juga masih cukup tinggi, sehingga diperlukan bentuk rekayasa yang tepat untuk proses aerob.

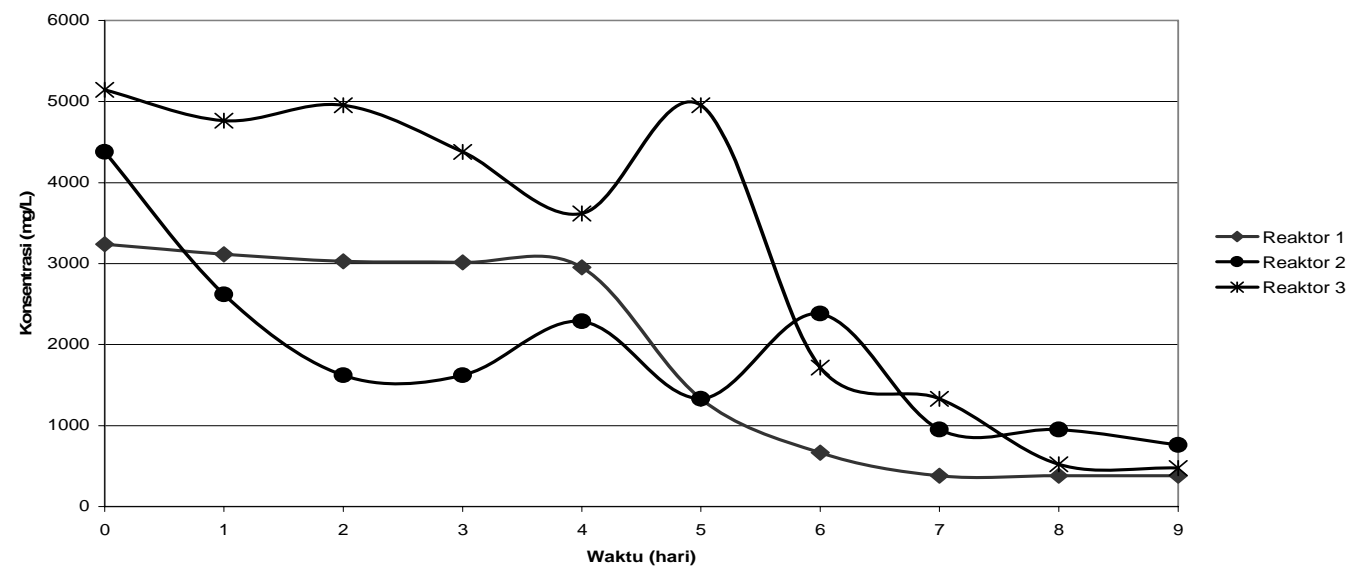

Gambar 8 Pola penyisihan senyawa organik pada konsentrasi 4000 mg/L COD secara aerob.

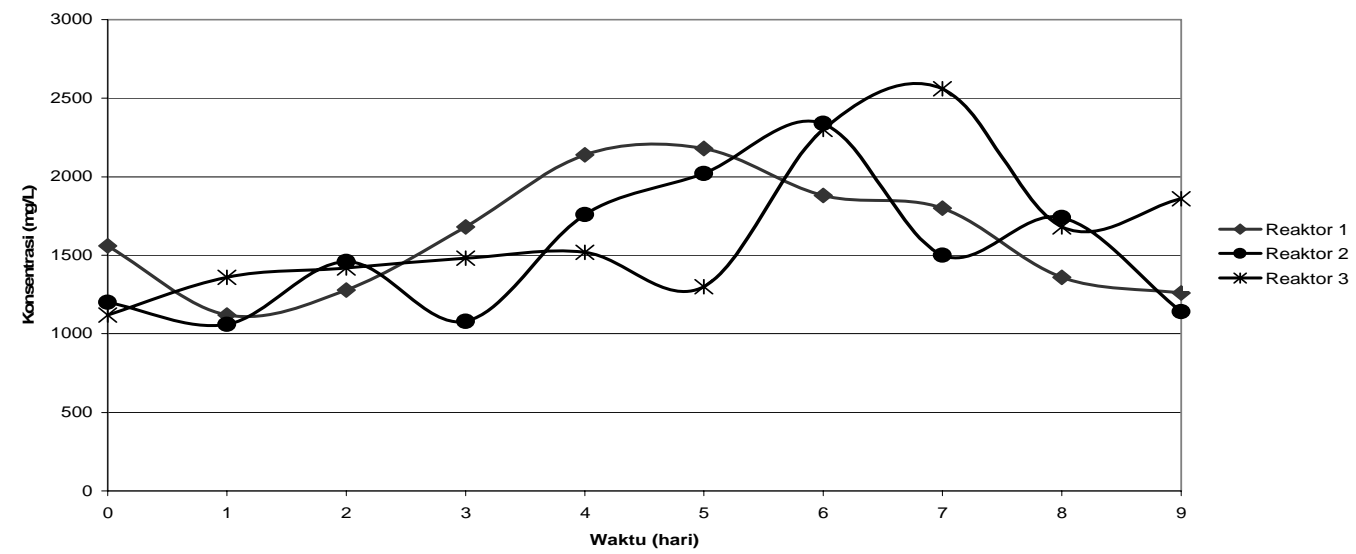

Gambar 9 Pola pertumbuhan mikroorganisma pada konsentrasi 4000 mg/L COD secara aerob. 


\section{$4 \quad$ Kesimpulan}

Dari hasil penelitian yang telah dilakukan dapat ditarik beberapa kesimpulan sebagai berikut:

1. Limbah industri biodiesel jika dilihat berdasarkan kandungan organik $\left(\mathrm{BOD}_{5}, \mathrm{COD}\right)$ dan padatan terlarut memiliki konsentrasi yang sangat tinggi.

2. Uji BMP sampai hari ke-23 memperlihatkan bahwa air limbah industri biodiesel relatif sulit terbiodegradasi secara anaerob.

3. Uji ATA memperlihatkan bahwa pada rentang volum limbah $0,4 \mathrm{~mL}$ sampai 1,2 mL belum menunjukkan adanya hambatan pada mikroorganisme metanogenesa.

4. Proses aerob dapat digunakan untuk menguraikan senyawa organik hingga konsentrasi awal limbah $5000 \mathrm{mg} / \mathrm{L}$, walaupun proses penyisihan senyawa organik belum optimal.

\section{Ucapan Terimakasih}

Penelitian ini didanai oleh Pusat Penelitian Sumber Daya Alam dan Pelestarian Lingkungan ITB, tahun 2005.

\section{Daftar Pustaka}

[1] Prakoso, T. \& Hidayat, A.N., Potensi Biodiesel Indonesia, 2006, http://www.migas-indonesia.com/files/article (diakses September 2006)

[2] Widodo, Perspektif Pengembangan Biodiesel di Indonesia, 2006, http://www.indeni.org/content/view/113/76/ (diakses September 2006).

[3] Howell, S. \& Weber, J.A., Biodiesel Use in Undergrpund Metal and Nonmetal Mines, 1997, http://www.dieselnet.com/papers/9705 howell.html (diakses September 2006)

[4] Syafila, M, Wisjnuprapto \& Susanti, S., The Influence of Hydrogen Concentration on End-Product Formation in Acidogenic Phase of Anaerobic Treatment of Palm Oil Mill Effluent Using Circulating Bed Reactor, Seminar on Research Findings assisted by the Asahi Glass Foundation (1992-1996), Bandung, 5 Desember, 1996.

[5] Owen, W.F., Stuckey, D.C., Healey, J.B., Young, L.Y. \& McCarty, P.L., Bioassay for Monitoring Biochemical Methane Potential and Anaerobic Toxicity, Water Res., 13, 485-492, 1979.

[6] Speece, R.E., Anaerobic Biotechnology for Industrial Wastewaters, Archae Press, Nashville, Tennessee, 1996.

[7] Bitton, G., Wastewater Microbiology, John Wiley and Sons, New York, 1994.

[8] Eckenfelder, W.W., Principles of Water Quality Management, Boston, CBI Publishing Company, Inc, 1980. 